\title{
Density functional theory, natural bond orbital and quantum theory of atoms in molecule analyses on the hydrogen bonding interactions in tryptophan-water complexes
}

\author{
XIQIAN NIU, ZHENGGUO HUANG*, LINGLING MA, TINGTING SHEN and LINGFEI GUO \\ Tianjin Key Laboratory of Structure and Performance for Functional Molecules, College of Chemistry, Tianjin \\ Normal University, Tianjin 300387, People's Republic of China \\ e-mail: hsxyhzg@126.com
}

MS received 23 October 2012; revised 15 January 2013; accepted 1 March 2013

\begin{abstract}
The tryptophan-water $\left(\operatorname{Trp}-\mathrm{H}_{2} \mathrm{O}\right)$ complexes formed by hydrogen bonding interactions were investigated at the $\omega \mathrm{B} 97 \mathrm{XD} / 6-311++\mathrm{G}(\mathrm{d}, \mathrm{p})$ level. Five Trp- $\mathrm{H}_{2} \mathrm{O}$ complexes possessing various types of hydrogen bonds (H-bonds) were characterized by geometries, energies, vibrational frequencies. The nature of the H-bonds were characterized by the natural bond orbital (NBO) and the quantum theory of atoms in molecule (QTAIM) analyses as well. The intramolecular H-bond formed between the amino and carboxyl oxygen atom of tryptophan was retained in most of the complexes, and the cooperativity between the intra and intermolecular H-bonds exist in some complexes. The intramolecular $\mathrm{H}$-bond and some intermolecular $\mathrm{H}$-bonds are strong and have partial covalent character. The H-bonds formed between carboxyl and oxygen/nitrogen atoms are stronger than other $\mathrm{H}$-bonds. The H-bonds involving methylene of tryptophan as $\mathrm{H}$-donor are weak $\mathrm{H}$-bonds. For all complexes, $\Delta E_{\text {ele }}$ and $\Delta E_{\text {ex }}$ makes major contributions to the total interaction energy $\left(\Delta E_{\mathrm{MP} 2}\right)$, while $\Delta E_{\text {disp }}$ is the smallest component of the interaction energy. Both hydrogen bonding interaction and structural deformation play important roles in the relative stabilities of the complexes. Regardless of strong H-bonds, the stabilities of some complexes are weakened by the serious structural deformations.
\end{abstract}

Keywords. Natural bond orbital (NBO); quantum theory of atoms in molecule (QTAIM); localized molecular orbital energy decomposition analysis (LMO-EDA); tryptophan; hydrogen bond.

\section{Introduction}

Tryptophan (Trp) is a kind of essential amino acid for humans and animals. Moreover, Trp has served as a useful probe of its local environment in proteins since the emission wavelength and excited-state lifetime depend on its environment. Trp is the only one amino acid which has both a complex structure and physiological and biochemical function in various amino acids. ${ }^{1,2}$ Trp was studied experimentally and theoretically in the ground and excited state ${ }^{3,4}$ because of its large absorption in the UV and its use as conformational fluorescence label in proteins. Most of the theoretical and experimental studies reported so far are devoted to the Trp and its various conformers. Levy and coworkers studied the UV spectroscopy of jet-cooled Trp and identified six different conformations in the resonantly enhanced two-photo ionization spectrum. ${ }^{5}$ Five of the six conformers were confirmed nicely by the highresolution vibronic spectra of Trp in $0.38 \mathrm{~K}$ cold helium droplets. ${ }^{6}$ Compagnon et al. measured the permanent

*For correspondence electric dipole of tryptophan isolated in a molecular beam at $85 \mathrm{~K},{ }^{7}$ which gave different results from that of the Levy group. A systematic and extensive conformational search for the gas-phase tryptophan has been performed by Huang and Lin, ${ }^{8}$ and the results support the conclusion drawn by Compagnon et al. that only one dominant isomer existed in the molecular beam at $85 \mathrm{~K}$ and add further evidence that the supersonic jet expansion or embedding helium droplets did not produce an equilibrium distribution. Recently, the photochemistry of the neutral and zwitterionic form with two water molecules were analysed with ab initio methods. ${ }^{9}$

In general, zwitterionic forms of amino acids are stabilized in the crystalline state and in a solution. On the other hand, the neutral form of amino acids is also found in the gas phase and low-temperature inert matrixes, which has stimulated extensive investigation of the transformation of Trp from the neutral form to the zwitterionic form. As previous researches have reported, eight or more water molecules may be necessary to render the zwitterionic structures of tryptophan-water $\left(\right.$ Trp- $\left.\mathrm{H}_{2} \mathrm{O}\right)$ complexes. ${ }^{9}$ The conformational picture of such $\operatorname{Trp}-\mathrm{H}_{2} \mathrm{O}$ complexes is 
considerably complicated and the calculation would be prohibitively expensive. However, the Trp- $\mathrm{H}_{2} \mathrm{O}$ complexes may serve as a useful model system for the exploration of tryptophan-water complexes that are characteristic for hydrated zwitterionic Trp. Preliminary knowledge of these mechanisms will certainly be helpful for the future exploration of the nature of Trp in larger complexes. In this paper, the structures of Trp- $\mathrm{H}_{2} \mathrm{O}$ complexes formed by the hydrogen bonding interaction between Trp and water was studied. The energetic, vibrational frequencies of $\mathrm{H}$-bonds were investigated. The quantum theory of atoms in molecules (QTAIM) $)^{10-12}$ and natural bond orbital (NBO) ${ }^{13}$ analyses were also carried out to study the nature of $\mathrm{H}$-bonds in $\mathrm{Trp}-\mathrm{H}_{2} \mathrm{O}$ complexes.

\section{Computational details}

All DFT calculations were performed with the Gaussian $09^{14}$ with the default convergence criteria without any constraint on the geometry. The $\omega \mathrm{B} 97 \mathrm{XD}$ functional $^{15}$ with the $6-311++\mathrm{G}(\mathrm{d}, \mathrm{p})$ basis set ${ }^{16,17}$ was used to investigate the electronic structure of the Trp$\mathrm{H}_{2} \mathrm{O}$ systems. The $\omega \mathrm{B} 97 \mathrm{XD}$ functional includes empirical dispersion and can better treat hydrogen bonding and van der Waals interactions than conventional DFT. In the beginning, the geometries of the isolated Trp and water monomers were fully optimized. The complexes were constructed starting from the most stable Trp and water monomers. All complexes were also fully optimized at the same level. The harmonic vibrational frequencies were calculated with analytic second derivatives at the same level, which confirm the structures as minima and enable the evaluation of zero-point vibrational energies (ZPVE). To take into account the effects of the basis set superposition error (BSSE), the counterpoise $(\mathrm{CP})$ correction $^{18}$ which was implemented in order to ensure that complexes and monomers are being computed with a consistent basis set. Finally, the interaction energies were calculated based on the ZPVE and BSSE corrections. In order to analyse the properties of the H-bond interactions in complexes, the QTAIM analyses were carried out using the wave functions obtained at $\omega \mathrm{B} 97 \mathrm{XD}$ at $6-311++\mathrm{G}(\mathrm{d}, \mathrm{p})$ level by the software AIM2000, ${ }^{19}$ the bond critical point (BCP) of H-bonds and its electron density topologic information can help us to evaluate the nature of H-bond. To understand the nature of hydrogen bonding interaction in complexes, the localized molecular orbital energy decomposition analysis (LMOEDA) ${ }^{20}$ were carried out using the Gamess electronic structure program code. ${ }^{21}$

\section{Results and discussion}

The proton transfer reaction mechanism in Trp moiety of Trp- $\mathrm{H}_{2} \mathrm{O}$ complex has been studied. ${ }^{22}$ In this work, the Trp and water monomers were optimized at the $\omega \mathrm{B} 97 \mathrm{XD} / 6-311++\mathrm{G}(\mathrm{d}, \mathrm{p})$ level and the molecular graphs were presented in figure 1. As shown in figure 1, Trp can offer several possible proton donor/acceptor sites to form H-bond. The hydroxyl or amino groups of Trp can donate proton to form H-bond. Moreover, the methylene of Trp also acts as a H-donor in some complexes. The oxygen atom of carbonyl is the major $\mathrm{H}$ acceptor of Trp, and the nitrogen atom of amino can act as $\mathrm{H}$-acceptor to form intramolecular $\mathrm{H}$-bond in some complexes.

\subsection{Structures}

In this article, different complexes were taken into account to analyse various types of H-bonds. All molecular graphs of optimized Trp- $\mathrm{H}_{2} \mathrm{O}$ complexes were shown in figure 2, and the structural parameters of $\mathrm{H}$-bonds were listed in table 1 . The vibrational frequency calculations confirmed that all optimized complexes have no imaginary frequencies and are stable structures. According to the QTAIM, both inter and intramolecular $\mathrm{H}$-bonds can be characterized by the BCPs between $\mathrm{H}$-donor $(\mathrm{X}-\mathrm{H})$ and $\mathrm{H}$-acceptor $(\mathrm{Y})$. Therefore, the existence of $\mathrm{BCP}$ and the electron density topological properties of $\mathrm{BCP}$ can be used to study the nature of $\mathrm{H}$-bond. Ring critical point (RCP) can also be found when a ring structure was formed due to multiple H-bonds. There are two RCPs related with the benzene and indolyl rings of Trp, which have no relationship with $\mathrm{H}$-bonds (figure 1). As shown in

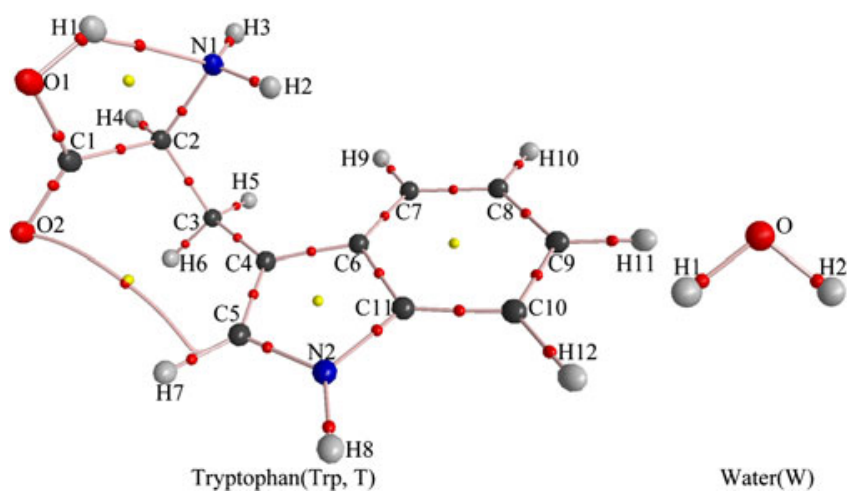

Figure 1. Molecular graphs of free Trp monomer. Large circles correspond to attractors attributed to atomic positions: gray, H; blue, N; black, C; red, O. Small circles are attributed to critical points: red, bond critical point; yellow, ring critical point. 

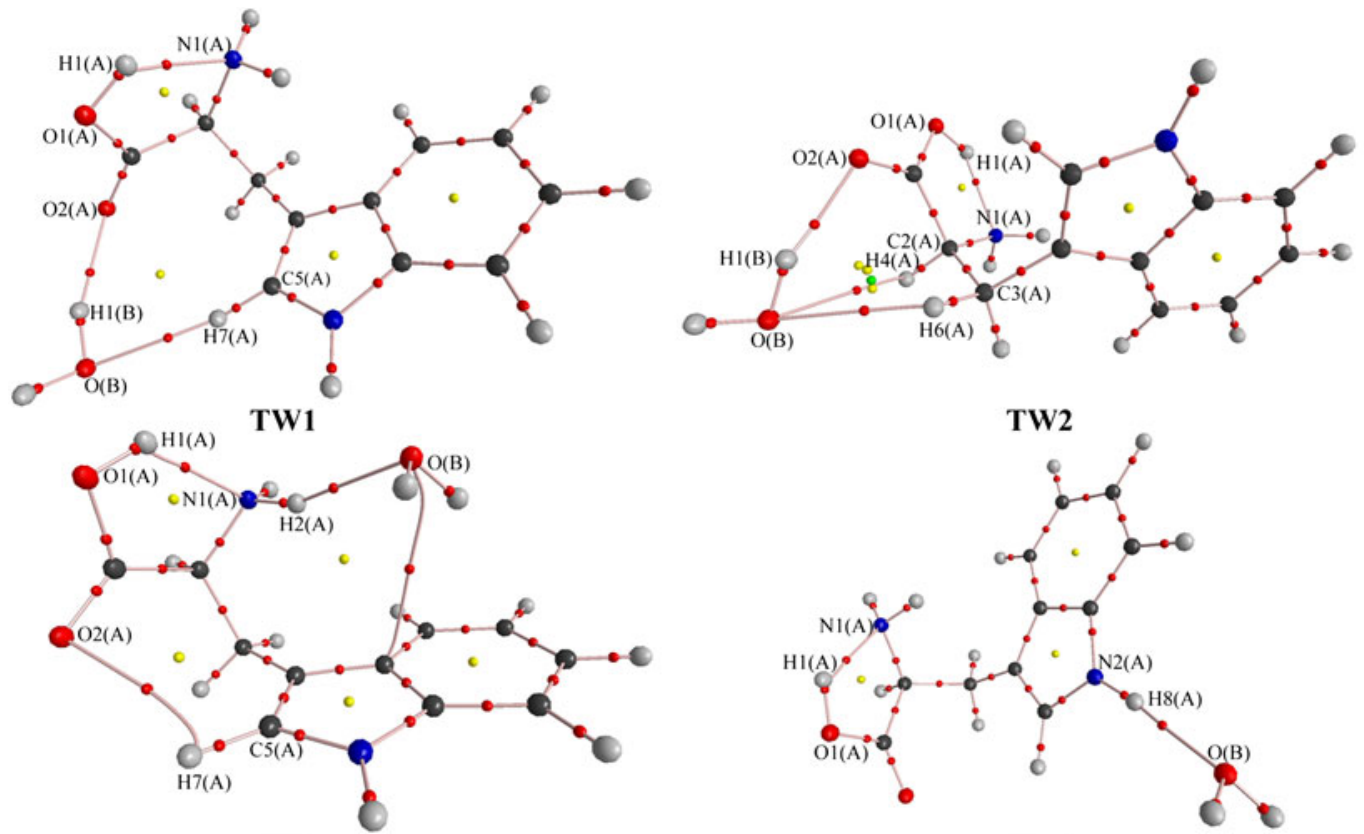

TW3

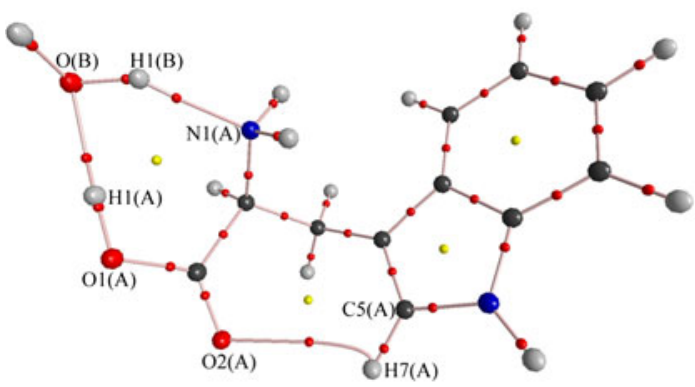

TW5

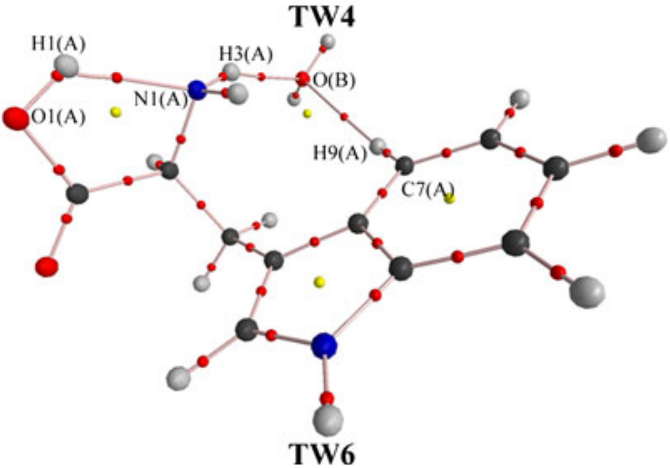

Figure 2. Molecular graphs of Trp- $\mathrm{H}_{2} \mathrm{O}$ complexes. Large circles correspond to attractors attributed to atomic positions: gray, $\mathrm{H}$; blue, N; black, C; red, O. Small circles are attributed to critical points: red, bond critical point; yellow, ring critical point.

figure 1 , due to the intramolecular $\mathrm{O} 1 \mathrm{H} 1^{\mathrm{T}} \cdots \mathrm{N} 1^{\mathrm{T}} \mathrm{H}$ bond in Trp monomer, a ring structure was formed and can be characterized by the BCP and corresponding RCP on the basis of QTAIM. Such intramolecular $\mathrm{O} 1 \mathrm{H} 1^{\mathrm{T}} \cdots \mathrm{N} 1^{\mathrm{T}} \mathrm{H}$-bond are retained in all Trp- $\mathrm{H}_{2} \mathrm{O}$ complexes except TW5. The cleavage of the intramolecular $\mathrm{O} 1 \mathrm{H} 1^{\mathrm{T}} \cdots \mathrm{N} 1^{\mathrm{T}}$ H-bond in TW5 indicates that the serious structural deformation occurred in TW5 than other complexes. The new intramolecular $\mathrm{C} 5 \mathrm{H} 7^{\mathrm{T}} \cdots \mathrm{O} 2^{\mathrm{T}} \mathrm{H}$-bond seems to be formed in TW3 and TW5, respectively. In addition, one cage structure was formed by multiple H-bonds in TW2 and is characterized by cage critical point (CCP).

As shown in figure 2, only one intermolecular $\mathrm{H}$ bond was formed between Trp and water in TW3 and TW4, respectively. However, because the distance between the centre of benzene ring and the proton of the hydroxyl of water in TW3 is about $2.520 \AA$, an $\pi$ $\mathrm{H}$-bond seems to be formed between the benzene ring and water molecule. When one water molecule is above the benzene ring, there is a tendency to form $\pi$ H-bond between them because the sucking-electron ability of benzene is very strong. Unfortunately, neither QTAIM nor NBO analyses can give direct evidence for such $\pi$ H-bond. For the other complexes (TW1, TW2 and TW5), multiple intermolecular H-bonds can be found, respectively.

Structural parameters of $\mathrm{H}$-bonds can provide some rough information on the nature of $\mathrm{H}$-bonds. It is well known that the $\mathrm{H}$-bond formation is connected with the elongation of the proton donating X-H bond (except of the special case of so-called blue-shifted H-bonds) as well as the shortening of $\mathrm{H} \cdots \mathrm{Y}$ bond. The shorter $\mathrm{H} \cdots \mathrm{Y}$ bond or the longer $\mathrm{X}-\mathrm{H}$ bond is, the stronger the interaction is, and vice versa. As shown in table 1, the $\mathrm{H}$-bonds taking methylene as $\mathrm{H}$-donor are very weak, which can be seen from the almost unchanged $\Delta \mathrm{R}_{\mathrm{X}-\mathrm{H}}$ and longer $R_{\mathrm{H} \cdot \mathrm{Y}}$ than about $2.2 \AA$. The other 
Table 1. Structural parameters (bond lengths in $\AA$, angles in degree) of $\mathrm{H}$-bonds in $\operatorname{Trp}-\mathrm{H}_{2} \mathrm{O}$ complexes calculated at the $\omega \mathrm{B} 97 \mathrm{XD} / 6-311++\mathrm{G}(\mathrm{d}, \mathrm{p})$ level.

\begin{tabular}{|c|c|c|c|c|c|c|}
\hline Complex & H-bond ${ }^{\mathrm{a}}$ & $R_{\mathrm{X}-\mathrm{H}}$ & $\Delta R_{\mathrm{X}-\mathrm{H}}{ }^{\mathrm{b}}$ & $R_{\mathrm{H} \cdots \mathrm{Y}}$ & $\delta R_{\mathrm{H} \cdots \mathrm{Y}}$ & $\angle \mathrm{X}-\mathrm{H} \cdots \mathrm{Y}$ \\
\hline \multirow[t]{3}{*}{ TW1 } & $\mathrm{OH} 1^{\mathrm{W}} \cdots \mathrm{O} 2^{\mathrm{T}}$ & 0.968 & 0.011 & 1.891 & 0.829 & 158.8 \\
\hline & $\mathrm{C} 5 \mathrm{H}^{\mathrm{T}} \cdots \mathrm{O}^{\mathrm{W}}$ & 1.082 & 0.002 & 2.246 & 0.474 & 163.9 \\
\hline & $\mathrm{O} 1 \mathrm{H} 1^{\mathrm{T}} \cdots \mathrm{N} 1^{\mathrm{T}}$ & 0.984 & 0.004 & 1.859 & 0.891 & 126.7 \\
\hline \multirow[t]{4}{*}{ TW2 } & $\mathrm{OH} 1^{\mathrm{W}} \cdots \mathrm{O} 2^{\mathrm{T}}$ & 0.969 & 0.012 & 1.893 & 0.827 & 158.9 \\
\hline & $\mathrm{C} 3 \mathrm{H}^{\mathrm{T}} \cdots \mathrm{O}^{\mathrm{W}}$ & 1.090 & -0.001 & 2.553 & 0.167 & 126.3 \\
\hline & $\mathrm{C} 2 \mathrm{H} 4^{\mathrm{T}} \cdots \mathrm{O}^{\mathrm{W}}$ & 1.094 & -0.002 & 2.674 & 0.046 & 112.6 \\
\hline & $\mathrm{O} 1 \mathrm{H} 1^{\mathrm{T}} \cdots \mathrm{N} 1^{\mathrm{T}}$ & 0.984 & 0.004 & 1.851 & 0.899 & 127.1 \\
\hline \multirow[t]{3}{*}{ TW3 } & $\mathrm{N} 1 \mathrm{H} 2^{\mathrm{T}} \cdots \mathrm{O}^{\mathrm{W}}$ & 1.020 & 0.004 & 2.114 & 0.606 & 160.4 \\
\hline & $\mathrm{C} 5 \mathrm{H} 7^{\mathrm{T}} \cdots \mathrm{O} 2^{\mathrm{T}}$ & 1.080 & 0.000 & 2.645 & 0.075 & 113.2 \\
\hline & $\mathrm{O} 1 \mathrm{H} 1^{\mathrm{T}} \cdots \mathrm{N} 1^{\mathrm{T}}$ & 0.982 & 0.002 & 1.877 & 0.873 & 125.5 \\
\hline \multirow[t]{2}{*}{ TW4 } & $\mathrm{N} 2 \mathrm{H} 8^{\mathrm{T}} \cdots \mathrm{O}^{\mathrm{W}}$ & 1.014 & 0.010 & 1.924 & 0.796 & 174.3 \\
\hline & $\mathrm{O} 1 \mathrm{H} 1^{\mathrm{T}} \cdots \mathrm{N} 1^{\mathrm{T}}$ & 0.980 & 0.000 & 1.880 & 0.870 & 126.1 \\
\hline \multirow[t]{3}{*}{ TW5 } & $\mathrm{O} 1 \mathrm{H} 1^{\mathrm{T}} \cdots \mathrm{O}^{\mathrm{W}}$ & 0.982 & 0.002 & 1.742 & 0.978 & 175.2 \\
\hline & $\mathrm{OH} 1^{\mathrm{W}} \cdots \mathrm{N} 1^{\mathrm{T}}$ & 0.982 & 0.025 & 1.839 & 0.911 & 149.3 \\
\hline & $\mathrm{C} 5 \mathrm{H} 7^{\mathrm{T}} \cdots \mathrm{O} 2^{\mathrm{T}}$ & 1.079 & -0.001 & 2.532 & 0.188 & 110.2 \\
\hline \multirow[t]{3}{*}{ TW6 } & $\mathrm{N} 1 \mathrm{H} 3^{\mathrm{T}} \cdots \mathrm{O}^{\mathrm{W}}$ & 1.015 & 0.004 & 2.135 & 0.585 & 158.4 \\
\hline & $\mathrm{C} 7 \mathrm{H}^{\mathrm{T}} \cdots \mathrm{O}^{\mathrm{W}}$ & 1.086 & 0.000 & 2.666 & 0.054 & 156.5 \\
\hline & $\mathrm{O} 1 \mathrm{H} 1^{\mathrm{T}} \cdots \mathrm{N} 1^{\mathrm{T}}$ & 0.981 & 0.001 & 1.885 & 0.865 & 125.6 \\
\hline \multirow{7}{*}{ Tryptophan } & $\mathrm{O} 1 \mathrm{H} 1^{\mathrm{T}} \cdots \mathrm{N} 1^{\mathrm{T}}$ & 0.980 & & 1.888 & 0.862 & 125.7 \\
\hline & $\mathrm{N} 1 \mathrm{H} 2$ & 1.016 & & & & \\
\hline & $\mathrm{N} 1 \mathrm{H} 3$ & 1.011 & & & & \\
\hline & N2H8 & 1.004 & & & & \\
\hline & C3H6 & 1.091 & & & & \\
\hline & $\mathrm{C} 2 \mathrm{H} 4$ & 1.096 & & & & \\
\hline & C5H7 & 1.080 & & & & \\
\hline $\mathrm{H}_{2} \mathrm{O}$ & $\mathrm{OH}$ & 0.957 & & & & \\
\hline
\end{tabular}

aSuperscript "T" denote Trp and "W" denote $\mathrm{H}_{2} \mathrm{O}$

${ }^{\mathrm{b}} \Delta R_{\mathrm{X}-\mathrm{H}}=R_{\mathrm{X}-\mathrm{H}}$ (complexes) $-R_{\mathrm{X}-\mathrm{H}}($ free monomer $)$

$\mathrm{H}$-bonds involving the hydroxyl or amino as $\mathrm{H}$-donor have positive $\Delta \mathrm{R}_{\mathrm{X}-\mathrm{H}}$ values and are red-shifted $\mathrm{H}$ bonds. The largest $\Delta \mathrm{R}_{\mathrm{X}-\mathrm{H}}(0.025 \AA)$ is found in the $\mathrm{OH} 1^{\mathrm{W}} \cdots \mathrm{N} 1^{\mathrm{T}}$ H-bond of TW5, which indicates that it seems to be the strongest intermolecular H-bond. It is worth noting that another intermolecular $\mathrm{H}$-bond $\left(\mathrm{O} 1 \mathrm{H} 1^{\mathrm{T}} \cdots \mathrm{O}^{\mathrm{W}}\right)$ in TW5 is also very strong although its $\Delta \mathrm{R}_{\mathrm{X}-\mathrm{H}}(0.002 \AA)$ is very small, moreover, and the intramolecular $\mathrm{O} 1 \mathrm{H} 1^{\mathrm{T}} \cdots \mathrm{N} 1^{\mathrm{T}} \mathrm{H}$-bond was destroyed by the formation of such intermolecular H-bonds, which lead to a smaller $\Delta \mathrm{R}_{\mathrm{X}-\mathrm{H}}$ of the $\mathrm{O} 1 \mathrm{H} 1^{\mathrm{T}} \cdots \mathrm{O}^{\mathrm{W}} \mathrm{H}$ bond compared to that of the $\mathrm{O} 1 \mathrm{H} 1^{\mathrm{T}} \cdots \mathrm{N} 1^{\mathrm{T}} \mathrm{H}$-bond. The shortest $R_{\mathrm{H} \ldots \mathrm{Y}}(1.742$ and $1.839 \AA)$ of the two H-bonds in TW5 further confirms that they are the two strongest intermolecular $\mathrm{H}$-bonds among all Trp$\mathrm{H}_{2} \mathrm{O}$ complexes. However, such strong hydrogen bonding interactions in TW5 does not mean it is the most stable complex since the cleavage of the intramolecular $\mathrm{O} 1 \mathrm{H} 1^{\mathrm{T}} \cdots \mathrm{N} 1^{\mathrm{T}} \mathrm{H}$-bond results in serious structural deformation which will be further discussed later.

The shorter $\mathrm{H} \cdots \mathrm{Y}$ bond means the stronger hydrogen bonding interaction. However, such a relationship is only a rough one, even if $R_{\mathrm{H} \ldots \mathrm{Y}}$ concern similar species immersed into similar environments. In other words, if the considered sample of $\mathrm{X}-\mathrm{H}$... Y systems is homogeneous. The estimation of H-bond strength directly on the basis of $R_{\mathrm{H} \ldots \mathrm{Y}}$ is not possible for a heterogeneous sample if $\mathrm{H}$-bonds differ in the type of $\mathrm{H}$-donor and/or $\mathrm{H}$-acceptor. In view of the above difficulties, a H-bond parameter $\delta \mathrm{R}_{\mathrm{H} \ldots \mathrm{Y}}$ which allow one to unify interactions to estimate their strength even if different pairs of atoms is defined as ${ }^{23}$

$$
\delta R_{\mathrm{H} \cdots \mathrm{Y}}=R_{\mathrm{H}}^{\mathrm{vDW}}+R_{\mathrm{Y}}^{\mathrm{vDW}}-R_{\mathrm{H} \cdots \mathrm{Y}}
$$

where $R_{\mathrm{H}}^{\mathrm{vDW}}$ and $R_{\mathrm{Y}}^{\mathrm{vDW}}$ are van der Waals radii of $\mathrm{H}$ and $\mathrm{Y}$ atoms given by Bondi, ${ }^{24}$ respectively, $R_{\mathrm{H} \cdots \mathrm{Y}}$ is the distance between $\mathrm{H}$-donor and $\mathrm{H}$-acceptor. As shown in table 1 , the $\delta \mathrm{R}_{\mathrm{H} \cdots \mathrm{Y}}$ of the intramolecular $\mathrm{O} 1 \mathrm{H} 1^{\mathrm{T}} \cdots \mathrm{N} 1^{\mathrm{T}}$ H-bond in all Trp- $\mathrm{H}_{2} \mathrm{O}$ complexes except TW5 is larger than that of Trp monomer, which indicates that the intramolecular $\mathrm{O} 1 \mathrm{H}^{\mathrm{T}} \cdots \mathrm{N} 1^{\mathrm{T}} \mathrm{H}$-bond was strengthened in complexes. The maximum of $\delta \mathrm{R}_{\mathrm{H} \ldots \mathrm{Y}}$ is $0.978 \AA$ of the intermolecular $\mathrm{O} 1 \mathrm{H} 1^{\mathrm{T}} \cdots \mathrm{O}^{\mathrm{W}} \mathrm{H}$-bond in TW5, which seems to be the strongest H-bond. Of course, 
another intermolecular $\mathrm{H}$-bond in TW5, $\mathrm{OH} 1^{\mathrm{W}} \cdots \mathrm{N} 1^{\mathrm{T}}$, is the second strongest $\mathrm{H}$-bond due to the second largest $\delta R_{\mathrm{H} \cdots \mathrm{Y}}(0.911 \AA)$. It is worth noting that the $\delta R_{\mathrm{H} \cdots \mathrm{Y}}$ of the $\mathrm{H}$-bonds taking methylene as H-donor is small, which implies that the $R_{H \ldots Y}$ is close to the sum of van der Waals radii of $\mathrm{H}$ and $\mathrm{Y}$ atoms. Therefore, from a structural viewpoint, the interaction between the methylene and $\mathrm{Y}$ atom is very weak and is the mixture of hydrogen bonding interaction and van der Waals interaction.

\subsection{Vibrational frequencies}

The harmonic vibrational frequencies and their shifts of H-bonds in Trp- $\mathrm{H}_{2} \mathrm{O}$ complexes and monomers calculated at the $\omega \mathrm{B} 97 \mathrm{XD} / 6-311++\mathrm{G}(\mathrm{d}, \mathrm{p})$ level were listed in table 2 . The red shifts in the $\mathrm{X}-\mathrm{H}$ stretching vibrational frequency have been traditionally considered one of the main fingerprints of $\mathrm{H}$-bonds, assuming that formation of an $\mathrm{H}$-bond weakens an $\mathrm{X}-\mathrm{H}$ single bond. The larger the shift value is, the stronger the $\mathrm{H}$ bond is. However, it is not easy to calculate the shifts of $\mathrm{X}-\mathrm{H}$ stretching vibrational modes if it mixes with other vibrational modes. For example, the intramolecular $\mathrm{O} 1 \mathrm{H} 1^{\mathrm{T}} \cdots \mathrm{N} 1^{\mathrm{T}}$ H-bond in Trp monomer lead to the mixture of the $\mathrm{O}-\mathrm{H}$ stretching with symmetric $\mathrm{NH}_{2}$ stretching vibration modes, which are calculated to be 3556.2 and $3536.5 \mathrm{~cm}^{-1}$, respectively. Similar things also happened in Trp- $\mathrm{H}_{2} \mathrm{O}$ complexes, so many $\Delta v_{\mathrm{X}-\mathrm{H}}$ values may be given for one $\mathrm{H}$-bond. As shown in table 2, the largest red-shifted values (about $380 \sim 490 \mathrm{~cm}^{-1}$ ) are found in the $\mathrm{OH} 1^{\mathrm{W}} \ldots \mathrm{N} 1^{\mathrm{T}}$ and $\mathrm{O} 1 \mathrm{H} 1^{\mathrm{T}} \cdots \mathrm{O}^{\mathrm{W}} \mathrm{H}$-bonds in TW5, which shows that the two H-bonds are the strongest red-shifted ones. The $\mathrm{OH} 1^{\mathrm{W}} \ldots \mathrm{O} 2^{\mathrm{T}}$ (TW1 and TW2) and $\mathrm{N} 2 \mathrm{H}^{\mathrm{T}} \cdots \mathrm{O}^{\mathrm{W}}$ (TW4) H-bonds have larger red-shifted values of about $140 \sim 180 \mathrm{~cm}^{-1}$, while other red-shifted H-bonds are tens of wavenumbers shift values. The $\mathrm{C} 5 \mathrm{H} 7^{\mathrm{T}} \cdots \mathrm{O}^{\mathrm{W}}$ $\mathrm{H}$-bond in TW1, is a red-shifted H-bond with negative $\Delta v_{\mathrm{X}-\mathrm{H}}$ of $28.6 \mathrm{~cm}^{-1}$, while other $\mathrm{H}$-bonds involving methylene are blue-shifted ones because of the positive shifts. Moreover, these H-bonds usually are weak since their shifts are small. In addition, the smaller $\Delta v_{\mathrm{X}-\mathrm{H}}$ values of the intramolecular $\mathrm{O} 1 \mathrm{H} 1^{\mathrm{T}} \cdots \mathrm{N} 1^{\mathrm{T}} \mathrm{H}$-bond do not mean that it is weak. On the contrary, it can seen from the negative $\Delta v_{\mathrm{X}-\mathrm{H}}$ values that the intramolecu$\operatorname{lar} \mathrm{O} 1 \mathrm{H} 1^{\mathrm{T}} \cdots \mathrm{N} 1^{\mathrm{T}} \mathrm{H}$-bond was strengthened during the formation process of Trp- $\mathrm{H}_{2} \mathrm{O}$ complex.

\subsection{QTAIM analyses}

To quantitatively study the nature of $\mathrm{H}$-bond, the QTAIM analysis has been carried out to deepen the nature of the H-bond interactions. QTAIM has been proved to be a powerful tool and technique to investigate hydrogen bonding interactions. ${ }^{23,25-29}$ For example, the characteristics of critical points provide additional information on the nature of interactions. The topological criteria of the existence of hydrogen bonding were proposed by Koch and Popelier. ${ }^{30}$ According to the criteria, $\mathrm{H}$-bonds should have a relatively high value of the electron density at the H. . Y BCP $\left(\rho_{b}\right)$, in the range 0.002-0.034 a.u., and the Laplacian of the electron density at $\mathrm{H} \cdots \mathrm{Y} \mathrm{BCP}\left(\nabla^{2} \rho_{b}\right)$ should be within the 0.024-0.139 a.u. ${ }^{31}$ Therefore, both $\rho_{b}$ and $\nabla^{2} \rho_{b}$ at the H. . Y BCP are good measures of the strength of $\mathrm{H}$-bond. Moreover, the criteria provide a basis to distinguish hydrogen bonding interactions from van der Waals interactions and have been proved to be valid for standard and nonconventional $\mathrm{H}$-bonds.

The other characteristics may be applied to describe the considered $\mathrm{BCP}$ and further the atom-atom interaction. There are well-known relationships resulting from the Virial theorem between energetic topological parameters and the Laplacian of electron density at BCP

$$
\begin{gathered}
(1 / 4) \nabla^{2} \rho_{b}=2 G_{b}+V_{b} \\
H_{b}=G_{b}+V_{b},
\end{gathered}
$$

where $G_{b}, V_{b}$ and $H_{b}$ are the kinetic, potential, and total electron energy densities at critical point, respectively. $G_{b}$ is a positive value, whereas $V_{b}$ is a negative one. The sign of $H_{b}$ depends on which contribution, potential or kinetic, will locally prevail on the BCP. The Laplacian is negative if the modulus of the potential energy outweighs two times the kinetic energy, which implies the covalent character of interaction, and it may concern covalent bonds as well as very strong H-bonds. If the modulus of the potential energy only one time outweighs the kinetic energy, the Laplacian is positive, but $H_{b}$ is negative, which implies the partial covalent character of interaction and concerns strong H-bonds. ${ }^{32,33}$ Moreover, the $\nabla^{2} \rho_{b}$ at the BCP is low and positive, which is typical of closed-shell interactions. Therefore, the following criterion of strength was proposed by Popelier: ${ }^{30}$ for weak and medium in strength H-bonds, $\nabla^{2} \rho_{b}>0$ and $H_{b}>0$; for strong H-bonds, $\nabla^{2} \rho_{b}>$ 0 and $H_{b}<0$; for very strong H-bonds, $\nabla^{2} \rho_{b}<0$ and $H_{b}<0$. This classification shows that weak $\mathrm{H}-$ bonds eventually merge with (weaker) van der Waals interactions whereas strong H-bonds merge, at the other end of the continuum, with covalent and polar bonds. The electronic topological properties at H. . Y Y BCPs of H-bonds including electron density $\left(\rho_{b}\right)$, the Laplacian of the electron density $\left(\nabla^{2} \rho_{b}\right)$, kinetic energy density $\left(G_{b}\right)$, potential energy density $\left(V_{b}\right)$ and total electron 
Table 2. The X-H stretching vibrational frequencies (strength) of $\mathrm{H}$-bonds in both $\mathrm{Trp}-\mathrm{H}_{2} \mathrm{O}$ complexes and monomers.

\begin{tabular}{|c|c|c|c|}
\hline Complex & H-bond & $v_{\mathrm{X}-\mathrm{H}}^{\mathrm{a}}$ & $\Delta v_{\mathrm{X}-\mathrm{H}}$ \\
\hline \multirow[t]{4}{*}{ TW1 } & $\mathrm{OH} 1^{\mathrm{W}} \cdots \mathrm{O} 2^{\mathrm{T}}$ & $3973.7(89$, as $)$ & -37.7 \\
\hline & & $3753.5(312, \mathrm{~s})$ & -148.5 \\
\hline & $\mathrm{C} 5 \mathrm{H} 7^{\mathrm{T}} \ldots \mathrm{O}^{\mathrm{W}}$ & $3243.6(68)$ & -28.6 \\
\hline & $\mathrm{O} 1 \mathrm{H} 1^{\mathrm{T}} \cdots \mathrm{N} 1^{\mathrm{T}}$ & $3541.2(31, \mathrm{~s})^{\mathrm{b}}, 3495.9(318, \mathrm{~s})^{\mathrm{b}}$ & $-15.0,-40.6$ \\
\hline \multirow[t]{6}{*}{ TW2 } & $\mathrm{OH} 1^{\mathrm{W}} \cdots \mathrm{O} 2^{\mathrm{T}}$ & $3972.7(97$, as $)$ & -38.7 \\
\hline & & $3720.8(372, \mathrm{~s})$ & -181.2 \\
\hline & $\mathrm{C} 3 \mathrm{H}^{\mathrm{T}} \cdots \mathrm{O}^{\mathrm{W}}$ & $3147.0(1$, as $)$ & 14.6 \\
\hline & & $3090.7(9, \mathrm{~s})^{\mathrm{c}}, 3080.2(14, \mathrm{~s})^{\mathrm{c}}$ & $11.6,12.2$ \\
\hline & $\mathrm{C} 2 \mathrm{H} 4^{\mathrm{T}} \cdots \mathrm{O}^{\mathrm{W}}$ & $3090.7(9, \mathrm{~s})^{\mathrm{c}}, 3080.2(14, \mathrm{~s})^{\mathrm{c}}$ & 11.6 \\
\hline & $\mathrm{O} 1 \mathrm{H} 1^{\mathrm{T}} \cdots \mathrm{N} 1^{\mathrm{T}}$ & $3488.4(303)$ & $-67.8,-48.1^{\mathrm{f}}$ \\
\hline \multirow[t]{4}{*}{ TW3 } & $\mathrm{N} 1 \mathrm{H} 2^{\mathrm{T}} \cdots \mathrm{O}^{\mathrm{W}}$ & $3644.3(30$, as $)$ & -1.0 \\
\hline & & $3517.2(210, \mathrm{~s}), 3482.5(187, \mathrm{~s})$ & $-39.0,-54.0$ \\
\hline & $\mathrm{C} 5 \mathrm{H} 7^{\mathrm{T}} \cdots \mathrm{O} 2^{\mathrm{T}}$ & $3283.4(2)$ & 11.2 \\
\hline & $\mathrm{O} 1 \mathrm{H} 1^{\mathrm{T}} \cdots \mathrm{N} 1^{\mathrm{T}}$ & $3517.2(210, \mathrm{~s})^{\mathrm{b}}, 3482.5(187, \mathrm{~s})^{\mathrm{b}}$ & $-39.0,-54.0$ \\
\hline \multirow[t]{2}{*}{ TW4 } & $\mathrm{N} 2 \mathrm{H} 8^{\mathrm{T}} \cdots \mathrm{O}^{\mathrm{W}}$ & $3578.5(685)$ & -140.3 \\
\hline & $\mathrm{O} 1 \mathrm{H} 1^{\mathrm{T}} \cdots \mathrm{N} 1^{\mathrm{T}}$ & $3544.6(81, \mathrm{~s})^{\mathrm{b}}, 3526.3(204, \mathrm{~s})^{\mathrm{b}}$ & $-11.6,-10.2$ \\
\hline \multirow[t]{4}{*}{ TW5 } & $\mathrm{O} 1 \mathrm{H} 1^{\mathrm{T}} \cdots \mathrm{O}^{\mathrm{W}}$ & $\begin{array}{c}3523.5(834, \mathrm{~s})^{\mathrm{d}}, 3515.7(648, \mathrm{~s})^{\mathrm{d}} \\
3419.7(276, \mathrm{~s})^{\mathrm{e}}\end{array}$ & $\begin{array}{c}-32.7,-20.8^{\mathrm{g}} \\
-482.4\end{array}$ \\
\hline & $\mathrm{OH} 1^{\mathrm{W}} \cdots \mathrm{N} 1^{\mathrm{T}}$ & $3523.5(834$, as $)$ & -487.9 \\
\hline & & $3523.5(834, \mathrm{~s})^{\mathrm{d}}, 3515.7(648, \mathrm{~s})^{\mathrm{d}}$ & $-386.3,-482.4^{\mathrm{g}}$ \\
\hline & $\mathrm{C} 5 \mathrm{H} 7^{\mathrm{T}} \cdots \mathrm{O} 2^{\mathrm{T}}$ & $3283.9(3)$ & 11.7 \\
\hline \multirow[t]{4}{*}{ TW6 } & $\mathrm{N} 1 \mathrm{H} 3^{\mathrm{T}} \ldots \mathrm{O}^{\mathrm{W}}$ & $3596.8(84$, as $)$ & -48.5 \\
\hline & & $3536.1(88, \mathrm{~s})^{\mathrm{b}}, 3515.0(244, \mathrm{~s})^{\mathrm{b}}$ & $-20.1,-21.5$ \\
\hline & $\mathrm{C} 7 \mathrm{H} 9^{\mathrm{T}} \ldots \mathrm{O}^{\mathrm{W}}$ & $3198.4(18)^{\mathrm{h}}, 3188.7(2)^{\mathrm{h}}, 3179.2(1)^{\mathrm{h}}$ & $-8.2,-6.2,-5.5$ \\
\hline & $\mathrm{O} 1 \mathrm{H} 1^{\mathrm{T}} \cdots \mathrm{N} 1^{\mathrm{T}}$ & $3536.1(88, \mathrm{~s})^{\mathrm{b}}, 3515.0(244, \mathrm{~s})^{\mathrm{b}}$ & $-20.1,-21.5$ \\
\hline \multirow[t]{2}{*}{$\mathrm{H}_{2} \mathrm{O}$} & $\mathrm{OH}$ & $4011.4(62$, as $)$ & \\
\hline & & $3902.0(12, \mathrm{~s})$ & \\
\hline \multirow[t]{9}{*}{ Tryptophan } & $\mathrm{O} 1 \mathrm{H} 1$ & $3556.2(172, \mathrm{~s})^{\mathrm{b}}, 3536.5(105, \mathrm{~s})^{\mathrm{b}}$ & \\
\hline & $\mathrm{N} 1 \mathrm{H} 2$ & $3645.3(27$, as $)$ & \\
\hline & & $3556.2(172, \mathrm{~s})^{\mathrm{b}}, 3536.5(105, \mathrm{~s})^{\mathrm{b}}$ & \\
\hline & $\mathrm{N} 2 \mathrm{H} 8$ & $3718.7(88)$ & \\
\hline & $\mathrm{C} 3 \mathrm{H} 6$ & $3132.4(5$, as $)$ & \\
\hline & & $3079.1(35, \mathrm{~s})^{\mathrm{c}}, 3068.0(13, \mathrm{~s})^{\mathrm{c}}$ & \\
\hline & $\mathrm{C} 7 \mathrm{H} 9$ & $3206.6(23)^{\mathrm{h}}, 3194.9(2)^{\mathrm{h}}, 3184.7(6)^{\mathrm{h}}$ & \\
\hline & $\mathrm{C} 2 \mathrm{H} 4$ & $3079.1(35, \mathrm{~s})^{\mathrm{c}}, 3068.0(13, \mathrm{~s})^{\mathrm{c}}$ & \\
\hline & $\mathrm{C} 5 \mathrm{H} 7$ & $3272.2(1)$ & \\
\hline
\end{tabular}

aAll frequencies are in $\mathrm{cm}^{-1}$ and the strength are in $\mathrm{km} \cdot \mathrm{mol}^{-1}$. "as" denotes the asymmetric stretching vibration mode, and "s" denotes the symmetric stretching vibration mode

${ }^{\mathrm{b}}$ The mixture exists between the symmetric $\mathrm{NH}_{2}$ stretching and the $\mathrm{O} 1 \mathrm{H} 1$ stretching vibration mode

${ }^{c}$ The mixture exists between the symmetric $\mathrm{CH}_{2}(\mathrm{H} 5 \mathrm{C} 3 \mathrm{H} 6)$ stretching vibration mode and the $\mathrm{C} 2 \mathrm{H} 4$ stretching vibration mode

${ }^{\mathrm{d}}$ The mixture exists between the symmetric $\mathrm{NH}_{2}$ stretching vibration mode and the $\mathrm{O} 1 \mathrm{H} 1$ (Trp, $\mathrm{T}$ ) as well as $\mathrm{OH} 1$ (water, W) stretching vibration modes

${ }^{\mathrm{e}}$ The mixture exists between the $\mathrm{O} 1 \mathrm{H} 1$ (Trp, T) stretching vibration mode and the $\mathrm{OH} 1$ (water, $\mathrm{W}$ ) stretching vibration modes f -67.8 and -48.1 are the $\Delta v_{\mathrm{X}-\mathrm{H}}$ values compared to the asymmetric and symmetric $\mathrm{H}-\mathrm{O}-\mathrm{H}$ stretching vibration mode of free water molecule, respectively

$\mathrm{g}-32.7$ and -20.8 are the $\Delta v_{\mathrm{X}-\mathrm{H}}$ values compared to the O1H1 (Trp, T) stretching vibration mode, while -386.3 and -482.4 are the $\Delta v_{\mathrm{X}-\mathrm{H}}$ values compared to the $\mathrm{OH}$ (water, $\mathrm{W}$ ) stretching vibration mode

${ }^{\mathrm{h}}$ The mixture exists among several $\mathrm{C}-\mathrm{H}$ stretching vibration modes of benzene ring

energy density $\left(H_{b}\right)$ of all complexes were listed in table 3.

As shown in table 3 , the intramolecular $\mathrm{O} 1 \mathrm{H} 1^{\mathrm{T}} \ldots$ $\mathrm{N} 1^{\mathrm{T}} \mathrm{H}$-bond in all the Trp- $\mathrm{H}_{2} \mathrm{O}$ complexes except $\mathbf{T W 5}$ is the strongest $\mathrm{H}$-bond since it have negative $H_{b}$ and positive $\nabla^{2} \rho_{b}$ values. Moreover, the value of $\rho_{b}$ is beyond the upper-limits of the range, which indicates that a partial covalent character is attributed to the 
Table 3. Electron density $\left(\rho_{b}\right)$, Laplacian of the electron density $\left(\nabla^{2} \rho_{b}\right)$, kinetic energy density $\left(G_{b}\right)$, potential energy density $\left(V_{b}\right)$ and total electron energy density $\left(H_{b}\right)$ in a.u. at BCPs of H-bonds in both $\operatorname{Trp}-\mathrm{H}_{2} \mathrm{O}$ complexes and Trp monomer by QTAIM analysis.

\begin{tabular}{|c|c|c|c|c|c|c|}
\hline Complex & H-bond & $\rho_{b}$ & $\nabla^{2} \rho_{b}$ & $V_{b}$ & $G_{b}$ & $H_{b}$ \\
\hline \multirow[t]{3}{*}{ TW1 } & $\mathrm{OH} 1^{\mathrm{W}} \cdots \mathrm{O} 2^{\mathrm{T}}$ & 0.02518 & 0.10199 & -0.01982 & 0.02266 & 0.00284 \\
\hline & $\mathrm{C} 5 \mathrm{H} 7^{\mathrm{T}} \cdots \mathrm{O}^{\mathrm{W}}$ & 0.01347 & 0.04649 & -0.00808 & 0.00985 & 0.00177 \\
\hline & $\mathrm{O} 1 \mathrm{H} 1^{\mathrm{T}} \cdots \mathrm{N} 1^{\mathrm{T}}$ & 0.04030 & 0.11332 & -0.03515 & 0.03174 & -0.00341 \\
\hline \multirow[t]{4}{*}{ TW2 } & $\mathrm{OH} 1^{\mathrm{W}} \ldots \mathrm{O} 2^{\mathrm{T}}$ & 0.02724 & 0.10036 & -0.02110 & 0.02310 & 0.00199 \\
\hline & $\mathrm{C} 3 \mathrm{H}^{\mathrm{T}} \cdots \mathrm{O}^{\mathrm{W}}$ & 0.00757 & 0.02890 & -0.00486 & 0.00604 & 0.00118 \\
\hline & $\mathrm{C} 2 \mathrm{H} 4^{\mathrm{T}} \cdots \mathrm{O}^{\mathrm{W}}$ & 0.00665 & 0.02459 & -0.00425 & 0.00520 & 0.00095 \\
\hline & $\mathrm{O} 1 \mathrm{H} 1^{\mathrm{T}} \cdots \mathrm{N} 1^{\mathrm{T}}$ & 0.04111 & 0.11416 & -0.03611 & 0.03233 & -0.00379 \\
\hline \multirow[t]{3}{*}{ TW3 } & $\mathrm{N} 1 \mathrm{H} 2^{\mathrm{T}} \cdots \mathrm{O}^{\mathrm{W}}$ & 0.01830 & 0.06262 & -0.01194 & 0.01380 & 0.00186 \\
\hline & $\mathrm{C} 5 \mathrm{H} 7^{\mathrm{T}} \cdots \mathrm{O} 2^{\mathrm{T}}$ & 0.00739 & 0.02623 & -0.00449 & 0.00552 & 0.00103 \\
\hline & $\mathrm{O} 1 \mathrm{H} 1^{\mathrm{T}} \cdots \mathrm{N} 1^{\mathrm{T}}$ & 0.03857 & 0.11228 & -0.03332 & 0.03070 & -0.00263 \\
\hline \multirow[t]{2}{*}{ TW4 } & $\mathrm{N} 2 \mathrm{H} 8^{\mathrm{T}} \cdots \mathrm{O}^{\mathrm{W}}$ & 0.02505 & 0.09665 & -0.01922 & 0.02169 & 0.00247 \\
\hline & $\mathrm{O} 1 \mathrm{H} 1^{\mathrm{T}} \cdots \mathrm{N} 1^{\mathrm{T}}$ & 0.03831 & 0.11228 & -0.03304 & 0.03055 & -0.00249 \\
\hline \multirow[t]{3}{*}{ TW5 } & $\mathrm{O} 1 \mathrm{H} 1^{\mathrm{T}} \cdots \mathrm{O}^{\mathrm{W}}$ & 0.03986 & 0.12730 & -0.03581 & 0.03382 & -0.00199 \\
\hline & $\mathrm{OH} 1^{\mathrm{W}} \cdots \mathrm{N} 1^{\mathrm{T}}$ & 0.04022 & 0.10450 & -0.03347 & 0.02980 & -0.00367 \\
\hline & $\mathrm{C} 5 \mathrm{H} 7^{\mathrm{T}} \cdots \mathrm{O} 2^{\mathrm{T}}$ & 0.00950 & 0.03458 & -0.00607 & 0.00736 & 0.00129 \\
\hline \multirow[t]{3}{*}{ TW6 } & $\mathrm{N} 1 \mathrm{H} 3^{\mathrm{T}} \cdots \mathrm{O}^{\mathrm{W}}$ & 0.01668 & 0.06166 & -0.01116 & 0.01329 & 0.00213 \\
\hline & $\mathrm{C} 7 \mathrm{H} 9^{\mathrm{T}} \ldots \mathrm{O}^{\mathrm{W}}$ & 0.00638 & 0.01961 & -0.00370 & 0.00430 & 0.00060 \\
\hline & $\mathrm{O} 1 \mathrm{H} 1^{\mathrm{T}} \cdots \mathrm{N} 1^{\mathrm{T}}$ & 0.03773 & 0.11162 & -0.03241 & 0.03016 & -0.00226 \\
\hline Tryptophan & $\mathrm{O} 1 \mathrm{H} 1^{\mathrm{T}} \cdots \mathrm{N} 1^{\mathrm{T}}$ & 0.03771 & 0.11163 & -0.03236 & 0.03013 & -0.00223 \\
\hline
\end{tabular}

intramolecular $\mathrm{O} 1 \mathrm{H} 1^{\mathrm{T}} \cdots \mathrm{N} 1^{\mathrm{T}} \mathrm{H}$-bond. The strength of the intramolecular $\mathrm{O} 1 \mathrm{H} 1^{\mathrm{T}} \cdots \mathrm{N} 1^{\mathrm{T}}$ H-bond in Trp$\mathrm{H}_{2} \mathrm{O}$ complexes can also been learnt from the larger $\rho_{b}$ and $\nabla^{2} \rho_{b}$ as well as more negative $H_{b}$ compared to those of Trp monomer. Similarly, due to the negative $H_{b}\left(-0.00367\right.$ and -0.00199 a.u.) and positive $\nabla^{2} \rho_{b}$ $(0.10450$ and 0.12730 a.u. $)$, the $\mathrm{OH}^{\mathrm{W}}{ }^{\mathrm{N}} \mathrm{N}^{\mathrm{T}}$ and $\mathrm{O} 1 \mathrm{H} 1^{\mathrm{T}} \cdots \mathrm{O}^{\mathrm{W}} \mathrm{H}$-bonds in TW5 are the two strongest intermolecular H-bonds among all Trp- $\mathrm{H}_{2} \mathrm{O}$ complexes. Moreover, a partial covalent character is attributed to them since their $\rho_{b}$ values $(0.04022$ and 0.03986 a.u.) are beyond the upper-limits of the range. For the other H-bonds, both $\rho_{b}$ and $\nabla^{2} \rho_{b}$ fall in the ranges proposed by Popelier, moreover, the $H_{b}$ values are positive, which indicates that these $\mathrm{H}$-bonds are of weak or medium strengths. Especially, for the H-bonds taking methylene as H-donor, both $\rho_{b}$ and $\nabla^{2} \rho_{b}$ are close to the lower-limit of criteria proposed by Popelier, which shows that they are very weak and are regarded as the mixture of hydrogen bonding interaction and van der Waals interaction. Therefore, for such extreme case, the existence of $\mathrm{BCP}$ is not the unique criterion to verify weak H-bond, and other methods (such as NBO) should be applied to investigate the nature of such interaction. Another embarrassment is that no direct QTAIM evidence can be found for $\pi$ H-bond formed between the benzene ring and the hydroxyl of water moiety in TW3.

To understand the relationship between $\delta R_{\mathrm{H} \ldots \mathrm{Y}}$ and topological parameters of QTAIM $\left(\rho_{b} \sim \delta R_{\mathrm{H} \ldots \mathrm{Y}}\right.$ and $\nabla^{2} \rho_{b} \sim \delta R_{\mathrm{H} \cdots \mathrm{Y}}$ ) were shown in figure 3, and the linear relationships between them can be expressed as

$$
\begin{aligned}
\nabla^{2} \rho_{\mathrm{b}} & =0.0113+0.1094 \delta R_{\mathrm{H} \cdots \mathrm{Y}} r=0.9784 \\
\rho_{\mathrm{b}} & =0.0016+0.0375 \delta R_{\mathrm{H} \cdots \mathrm{Y}} r=0.9357
\end{aligned}
$$

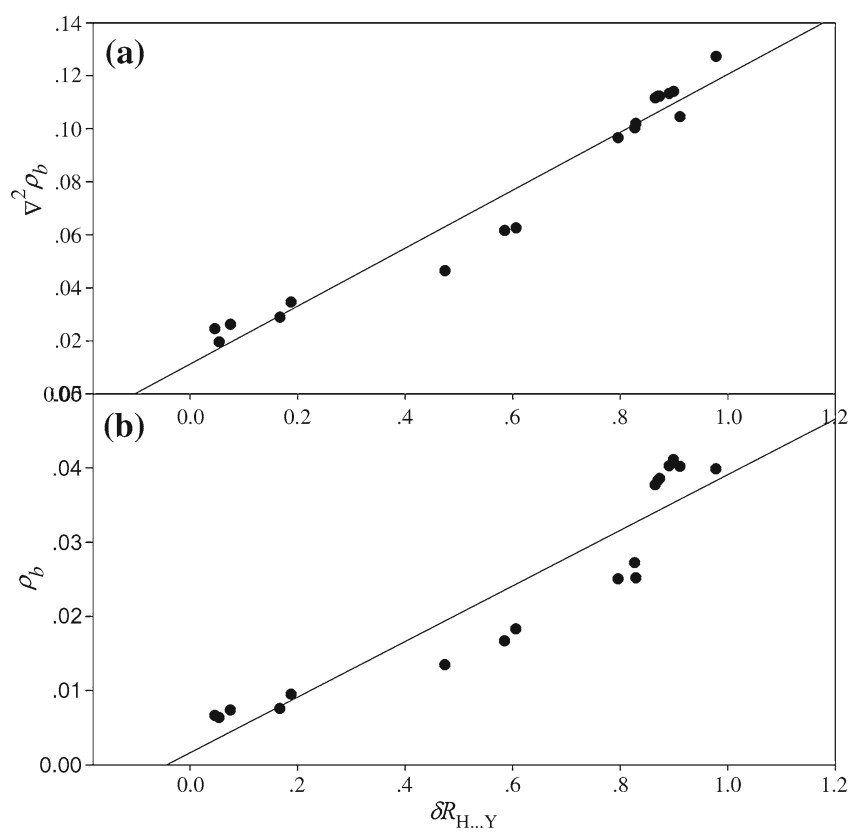

Figure 3. Correlation between $\delta R_{\mathrm{H} \ldots \mathrm{Y}}$ and H-bond parameters of QTAIM. (a) $\delta R_{\mathrm{H} \cdots \mathrm{Y}} \sim \nabla^{2} \rho_{b}$; (b) $\delta R_{\mathrm{H}} \sim \rho_{b}$. 
It can be learnt that $\rho_{b}$ is a linearly correlate to $\delta R_{\mathrm{H} \ldots \mathrm{Y}}$ substantially, while a better linear relationship exists between $\nabla^{2} \rho_{b}$ and $\delta R_{\mathrm{H} \cdots \mathrm{Y}}$.

\subsection{NBO and energy decomposition analyses}

Generally, a certain amount of charge transfer (CT) from the $\mathrm{H}$-acceptor to the $\mathrm{H}$-donor is one of the characteristics attributed to H-bond, which lead to a rearrangement of electron density within each part of the molecule. Although QTAIM analysis can provide relevant information on the strength of H-bonds in Trp$\mathrm{H}_{2} \mathrm{O}$ complexes, it cannot provide information on the CT. The NBO method ${ }^{13}$ shows that for typical hydrogen bonding, a two-electron $n_{B} \rightarrow \sigma_{X H}^{*}$ intermolecular donor-acceptor interaction exists where electron density from the lone pair $n_{B}$ of the $\mathrm{H}$-acceptor delocalizes into the unfilled $\sigma_{A H}{ }^{*}$ anti-bonding orbital of the $\mathrm{H}$-donor. The $n_{B} \rightarrow \sigma_{X H}^{*}$ orbital overlap is characteristic for hydrogen bonding interaction. The hydrogen bond formation leads to an increase of the occupancy of the $\sigma_{X H}^{*}$ antibond orbital and hence the weakening and lengthening of the $\mathrm{X}-\mathrm{H}$ bond. This leads to the red-shifted $v_{\mathrm{X}-\mathrm{H}}$ stretching frequency. Therefore, electron delocalization or CT effects between $n_{B}$ and $\sigma_{X H}^{*}$ may be estimated by second-order perturbation theory:

$$
E(2)=-2 \frac{\left\langle n_{B}|F| \sigma_{X H}^{*}\right\rangle^{2}}{\varepsilon\left(\sigma_{X H}^{*}\right)-\varepsilon\left(n_{B}\right)},
$$

where $\left\langle n_{B}|F| \sigma_{X H}^{*}\right\rangle$ is the Fock matrix element between the $n_{B}$ and $\sigma_{X H}^{*}$ orbitals, $\varepsilon\left(\sigma_{X H}^{*}\right)-\varepsilon\left(n_{B}\right)$ is the orbital energy difference (the difference of diagonal Fock matrix element). ${ }^{34}$ It is worth mentioning that the CT and the corresponding lowering of energy are attributed to hydrogen bonding interactions. In other words, the second-perturbation energies $E(2)$ lowering is responsible for the orbital interaction of $\mathrm{H}$-bond, the larger $E(2)$ values correspond to stronger $\mathrm{CT}$ interaction occurred in the $\mathrm{H}$-bond.

The result of NBO analysis was listed in table 4. As shown in table 4, the $\mathrm{O}$ atom involved as $\mathrm{H}$-acceptor has two branches: one has 'sp' hybrid characteristics, and the other one has 'p' hybrid characteristics; they correspond to two $E(2)$ values, respectively. On the contrary, the $\mathrm{N}$ atom involved as $\mathrm{H}$-acceptor shows 'sp' characteristics. The sum of $E(2)$ value of $59.51 \mathrm{kcal} \cdot \mathrm{mol}^{-1}$ in the $\mathrm{N} 2 \mathrm{H} 8^{\mathrm{T}} \cdots \mathrm{O}^{\mathrm{W}} \mathrm{H}$-bond of $\mathbf{T W} 4$ is the largest, which indicates the strongest $\mathrm{CT}$ interaction is responsible for the H-bond. Similarly, strong CT interaction in the $\mathrm{O} 1 \mathrm{H} 1^{\mathrm{T}} \ldots \mathrm{O}^{\mathrm{W}} \mathrm{H}$-bond of TW5 is also confirmed by the larger sum of $E(2)$ value of $51.31 \mathrm{kcal} \cdot \mathrm{mol}^{-1}$. Moreover, such strong CT effects in the $\mathrm{N} 2 \mathrm{H} 8^{\mathrm{T}} \cdots \mathrm{O}^{\mathrm{W}}$ (TW4) and $\mathrm{O} 1 \mathrm{H} 1^{\mathrm{T}} \cdots \mathrm{O}^{\mathrm{W}}$ (TW5) H-bond further confirm the partial covalent character of these H-bonds, which is consistent with above discussion. For other Hbonds except the $\mathrm{OH} 1^{\mathrm{W}} \ldots \mathrm{O} 2^{\mathrm{T}} \mathrm{H}$-bond in TW2, due to the smaller $E(2)$ less than about $10.0 \mathrm{kcal} \cdot \mathrm{mol}^{-1}$, weaker $\mathrm{CT}$ interaction occurred in them. Especially, no $E(2)$ values were found for the $\mathrm{C} 5 \mathrm{H} 7^{\mathrm{T}} \cdots \mathrm{O} 2^{\mathrm{T}} \mathrm{H}$-bond in TW3 and TW5, respectively, which indicates that the major contribution to such $\mathrm{H}$-bond comes from non-CT interaction rather than $\mathrm{CT}$ interaction.

The $E(2)$ values of intramolecular $\mathrm{O} 1 \mathrm{H} 1^{\mathrm{T}} \cdots \mathrm{N} 1^{\mathrm{T}}$ H-bond in some complexes (TW1, TW2 and TW3) are significantly larger than that of Trp monomer, which shows that stronger $\mathrm{CT}$ effect occurred in these complexes due to the intermolecular H-bond. In other words, there exists a certain cooperative effects between the intramolecular $\mathrm{O} 1 \mathrm{H} 1^{\mathrm{T}} \cdots \mathrm{N} 1^{\mathrm{T}} \mathrm{H}$-bond and intermolecular $\mathrm{H}$-bonds in these complexes (TW1, TW2 and TW3). There are structural evidences for such cooperativity. The positive $\Delta \mathrm{R}_{\mathrm{X}-\mathrm{H}}$ values of the

Table 4. The second-perturbation energies $E(2)$ (in $\mathrm{kcal} \cdot \mathrm{mol}^{-1}$ ) of H-bonds in both $\mathrm{Trp}-\mathrm{H}_{2} \mathrm{O}$ complexes obtained by NBO analysis.

\begin{tabular}{|c|c|c|c|c|c|}
\hline Complex & H-bond & $E(2)^{\mathrm{a}}$ & Complex & H-bond & $E(2)^{\mathrm{a}}$ \\
\hline \multirow[t]{3}{*}{ TW1 } & $\mathrm{OH} 1^{\mathrm{W}} \ldots \mathrm{O} 2^{\mathrm{T}}$ & $3.66(1.34)$ & \multirow[t]{2}{*}{ TW4 } & $\mathrm{N} 2 \mathrm{H}^{\mathrm{T}} \cdots \mathrm{O}^{\mathrm{W}}$ & $8.04(51.47)$ \\
\hline & $\mathrm{C} 5 \mathrm{H}^{\mathrm{T}} \ldots \mathrm{O}^{\mathrm{W}}$ & $0.59(4.45)$ & & $\mathrm{O} 1 \mathrm{H} 1^{\mathrm{T}} \cdots \mathrm{N} 1^{\mathrm{T}}$ & 3.63 \\
\hline & $\mathrm{O} 1 \mathrm{H} 1^{\mathrm{T}} \cdots \mathrm{N} 1^{\mathrm{T}}$ & 15.62 & TW5 & $\mathrm{O} 1 \mathrm{H} 1^{\mathrm{T}} \cdots \mathrm{O}^{\mathrm{W}}$ & $44.12(7.19)$ \\
\hline \multirow[t]{4}{*}{ TW2 } & $\mathrm{OH} 1^{\mathrm{W}} \ldots \mathrm{O} 2^{\mathrm{T}}$ & $9.12(7.79)$ & \multirow{4}{*}{ TW6 } & $\mathrm{OH} 1^{\mathrm{W}} \cdots \mathrm{N} 1^{\mathrm{T}}$ & 8.27 \\
\hline & $\mathrm{C} 3 \mathrm{H}^{\mathrm{T}} \cdots \mathrm{O}^{\mathrm{W}}$ & $9.63(0.17)$ & & $\mathrm{N} 1 \mathrm{H} 3^{\mathrm{T}} \ldots \mathrm{O}^{\mathrm{W}}$ & 2.15 \\
\hline & $\mathrm{C} 2 \mathrm{H} 4^{\mathrm{T}} \cdots \mathrm{O}^{\mathrm{W}}$ & $0.81(1.77)$ & & $\mathrm{C} 7 \mathrm{H} 9^{\mathrm{T}} \cdots \mathrm{O}^{\mathrm{W}}$ & $1.53(8.72)$ \\
\hline & $\mathrm{O} 1 \mathrm{H} 1^{\mathrm{T}} \cdots \mathrm{N} 1^{\mathrm{T}}$ & 17.44 & & $\mathrm{O} 1 \mathrm{H} 1^{\mathrm{T}} \cdots \mathrm{N} 1^{\mathrm{T}}$ & 13.48 \\
\hline \multirow[t]{2}{*}{ TW3 } & $\mathrm{N} 1 \mathrm{H}_{2}{ }^{\mathrm{T}} \cdots \mathrm{O}^{\mathrm{W}}$ & $0.23(7.01)$ & \multirow[t]{2}{*}{ Tryptophan } & $\mathrm{O} 1 \mathrm{H} 1^{\mathrm{T}} \cdots \mathrm{N} 1^{\mathrm{T}}$ & \multirow[t]{2}{*}{2.13} \\
\hline & $\mathrm{O} 1 \mathrm{H} 1^{\mathrm{T}} \cdots \mathrm{N} 1^{\mathrm{T}}$ & 12.93 & & & \\
\hline
\end{tabular}

aThe values are $\mathrm{O}$ 'sp' hybrid branch to form the H-bond; those in the parentheses are $\mathrm{O}$ 'p' hybrid branch. The lone pair of $\mathrm{N}$ atom is mainly of 'p' character. See discussion in the text. 
Table 5. The LMO-EDA results of Trp- $\mathrm{H}_{2} \mathrm{O}$ complexes at the MP2/6-311++G(d,p) level. ${ }^{\mathrm{a}}$

\begin{tabular}{lrrrrrr}
\hline Complex & $\Delta_{\text {Eele }}$ & $\Delta E_{\text {ex }}$ & $\Delta E_{\text {rep }}$ & $\Delta E_{\text {pol }}$ & $\Delta E_{\text {disp }}$ & $\Delta E_{\mathrm{MP} 2}$ \\
\hline TW1 & $-13.58(41 \%)$ & $-14.64(45 \%)$ & 26.07 & $-3.98(12 \%)$ & $-0.53(2 \%)$ & -6.67 \\
TW2 & $-13.06(40 \%)$ & $-14.75(45 \%)$ & 26.27 & $-3.74(12 \%)$ & $-0.91(3 \%)$ & -6.19 \\
TW3 & $-9.95(32 \%)$ & $-14.88(48 \%)$ & 25.37 & $-2.64(9 \%)$ & $-3.26(11 \%)$ & -5.36 \\
TW4 & $-9.79(42 \%)$ & $-9.63(41 \%)$ & 17.52 & $-2.76(12 \%)$ & $-1.14(5 \%)$ & -5.81 \\
TW5 & $-29.21(35 \%)$ & $-39.67(47 \%)$ & 73.63 & $-12.04(14 \%)$ & $-3.12(4 \%)$ & -10.41 \\
TW6 & $-6.96(40 \%)$ & $-8.03(46 \%)$ & 13.72 & $-1.64(9 \%)$ & $-0.95(5 \%)$ & -3.86 \\
\hline
\end{tabular}

${ }^{\mathrm{a}}$ All energy are in $\mathrm{kcal} \cdot \mathrm{mol}^{-1}$ except the total energy (in Hartree)

intramolecular $\mathrm{O} 1 \mathrm{H} 1^{\mathrm{T}} \cdots \mathrm{N} 1^{\mathrm{T}} \mathrm{H}$-bond in some complexes (TW1, TW2 and TW3) implies that it was the strengthened due to the cooperativity between the intraand inter-molecular H-bonds. On the contrary, without such cooperativity, the $E(2)$ of the intramolecular $\mathrm{O} 1 \mathrm{H} 1^{\mathrm{T}} \cdots \mathrm{N} 1^{\mathrm{T}} \mathrm{H}$-bond in TW4 has a small change compared to that of Trp monomer since the intermolecular H-bond is away from the side chain of Trp, which can be seen from the unchanged $\Delta \mathrm{R}_{\mathrm{X}-\mathrm{H}}$ as well.

To explore the nature of hydrogen bonding interaction, an LMO-EDA ${ }^{20}$ calculations with the MP2 method was carried out, and the results were listed in table 5. In LMO-EDA, total interaction energy $\Delta E_{\mathrm{MP} 2}$ is decomposed into five terms:

$$
\Delta E_{\mathrm{MP} 2}=\Delta E_{\mathrm{ele}}+\Delta E_{\mathrm{ex}}+\Delta E_{\mathrm{rep}}+\Delta E_{\mathrm{pol}}+\Delta E_{\mathrm{disp}},
$$

where $\Delta E_{\text {ele }}$ is the electrostatic energy, $\Delta E_{\text {ex }}$ is the exchange energy, $\Delta E_{\text {rep }}$ is the repulsion energy, $\Delta E_{\text {pol }}$ is the polarization energy and $\Delta E_{\text {disp }}$ is the dispersion energy. As shown in table 5, the total interaction energy $\left(\Delta E_{\mathrm{MP} 2}\right)$ between $\operatorname{Trp}$ and $\mathrm{H}_{2} \mathrm{O}$ is in the range of about $-3.86 \sim-10.41 \mathrm{kcal} \cdot \mathrm{mol}^{-1}$. The $\Delta E_{\mathrm{MP} 2}$ $\left(-10.41 \mathrm{kcal} \cdot \mathrm{mol}^{-1}\right)$ of TW5 is the largest among all complexes. However, the cleavage of the intramolecular $\mathrm{O} 1 \mathrm{H} 1^{\mathrm{T}} \cdots \mathrm{N} 1^{\mathrm{T}} \mathrm{H}$-bond led to the serious structural deformation, which does not favour the stability of TW5. The largest stabilizing force in TW5 is the exchange interaction of $-39.67 \mathrm{kcal} \cdot \mathrm{mol}^{-1}$, which is counteracted simultaneously by the repulsion energy of $-73.637 \mathrm{kcal} \cdot \mathrm{mol}^{-1}$, so the exchang-repulsion energy is unfavourable for the stability of TW5. The second largest stabilizing force is the electrostatic energy of about $-29.21 \mathrm{kcal} \cdot \mathrm{mol}^{-1}$. Although the polarization energy of $-12.04 \mathrm{kcal} \cdot \mathrm{mol}^{-1}$ in TW5 is the largest among all complexes, $\Delta E_{\mathrm{pol}}$ makes a minor contribution to the total interaction energy between Trp and $\mathrm{H}_{2} \mathrm{O}$. Similar trends were found in other Trp- $\mathrm{H}_{2} \mathrm{O}$ complexes except TW5, $\Delta E_{\text {ele }}$ and $\Delta E_{\text {ex }}$ makes major contributions to the total interaction energy $\left(\Delta E_{\mathrm{MP} 2}\right)$ of complexes, while $\Delta E_{\text {disp }}$ is the smallest component of the interaction energy.

\section{Conclusions}

In this paper, we studied the geometries, energies and IR characteristics of the H-bonds of Trp- $\mathrm{H}_{2} \mathrm{O}$ complexes at the $\omega \mathrm{B} 97 \mathrm{XD} / 6-311++\mathrm{G}(\mathrm{d}, \mathrm{p})$ level. The intramolecular $\mathrm{O} 1 \mathrm{H} 1^{\mathrm{T}} \cdots \mathrm{N} 1^{\mathrm{T}} \mathrm{H}$-bond are retained in all complexes except TW5, and the cooperativity between the intra- and intermolecular $\mathrm{H}$-bonds exist in TW1, TW2 and TW3, respectively. The intramolecular $\mathrm{O} 1 \mathrm{H} 1^{\mathrm{T}} \cdots \mathrm{N} 1^{\mathrm{T}} \mathrm{H}$-bond and the intermolecular $\mathrm{H}$ bonds $\left(\mathrm{OH} 1^{\mathrm{W}} \cdots \mathrm{N} 1^{\mathrm{T}}\right.$ and $\left.\mathrm{O} 1 \mathrm{H} 1^{\mathrm{T}} \cdots \mathrm{O}^{\mathrm{W}}\right)$ in $\mathbf{T W 5}$ are strong and have partial covalent character. The $\mathrm{H}$ bonds involving methylene of Trp as H-donors are weak ones, especially the $\mathrm{C} 5 \mathrm{H} 7^{\mathrm{T}} \ldots \mathrm{O} 2^{\mathrm{T}} \mathrm{H}$-bond in $\mathbf{T W} 3$ and TW5 are derived from non-CT interaction since no CT evidence provided by NBO analyses. There exists an $\pi$ $\mathrm{H}$-bond in TW3 which involves the benzene ring as the $\mathrm{H}$-acceptor. Unfortunately, no direct NBO or QTAIM evidences confirm to such $\pi$ H-bond. For all complexes, $\Delta E_{\text {ele }}$ and $\Delta E_{\text {ex }}$ makes major contributions to the total interaction energy $\left(\Delta E_{\mathrm{MP} 2}\right)$, while $\Delta E_{\text {disp }}$ is the smallest component of the interaction energy. Both hydrogen bonding interaction and structural deformation play important roles in the relative stabilities of the complexes. Regardless of strong H-bond, the stability of TW5 is weakened by the serious structural deformation. In conclusion, the variety of the hydrogen bonding motifs that occur in the studied complexes may be helpful to further understand the hydrogen bonding interactions between Trp and other small organic molecules.

\section{Acknowledgement}

This work is supported by the Natural Science Foundation of Tianjin (No. 12JCYBJC13400).

\section{References}

1. Kapteina S, Slowik K, Verevkin S P and Heintz A 2005 J. Chem. Eng. Data $\mathbf{5 0} 398$

2. Pratuangdejkul J, Nosoongnoen W, Guerin G A, Loric S, Conti M, Launay J M and Manivet P 2006 Chem. Phys. Lett. 420538 
3. Blom M N, Compagnon I, Polfer N C, von Helden G, Meijer G, Suhai S, Paizs B and Oomens J 2007 J. Phys. Chem. A 1117309

4. Blancafort L, Gonzalez D, Olivucci M and Robb M A 2002 J. Am. Chem. Soc. 1246398

5. Rizzo T R, Park Y D, Peteanu L and Levy D H 1985 J. Chem. Phys. 834819

6. Lindinger A, Toennies J P and Vilesov A F 1999 J. Chem. Phys. 1101429

7. Compagnon I, Hagemeister F C, Antoine R, Rayane D, Broyer M, Dugourd P, Hudgins R R and Jarrold M F 2001 J. Am. Chem. Soc. 1238440

8. Huang Z J and Lin Z J 2005 J. Phys. Chem. A 1092656

9. Sobolewski A L, Shemesh D and Domcke W 2009 J. Phys. Chem. A 113542

10. Bader R F W 2006 Chem. Phys. Lett. 426226

11. Yarbrough L W, Calder G V and Verkade J G 1973 J. Chem. Soc. Chem. Commun. 705

12. Kosov D S and Popelier P L A 2000 J. Phys. Chem. A 1047339

13. Reed A E, Weinhold F, Curtiss L A and Pochatko D J 1986 J. Chem. Phys. 845687

14. Frisch M J, Trucks G W, Schlegel H B, Scuseria G E, Robb M A, Cheeseman J R, Scalmani G, Barone V, Mennucci B, Petersson G A, Nakatsuji H, Caricato M, Li X, Hratchian H P, Izmaylov A F, Bloino J, Zheng G, Sonnenberg J L, Hada M, Ehara M, Toyota K, Fukuda R, Hasegawa J, Ishida M, Nakajima T, Honda Y, Kitao O, Nakai H, Vreven T, Montgomery Jr. J A, Peralta J E, Ogliaro F, Bearpark M, Heyd J J, Brothers E, Kudin K N, Staroverov V N, Kobayashi R, Normand J, Raghavachari K, Rendell A, Burant J C, Iyengar S S, Tomasi J, Cossi M, Rega N, Millam J M, Klene M, Knox J E, Cross J B, Bakken V, Adamo C, Jaramillo J, Gomperts R, Stratmann R E, Yazyev O, Austin A J, Cammi R, Pomelli C, Ochterski J W, Martin R L, Morokuma K, Zakrzewski V G, Voth G A, Salvador P, Dannenberg J J, Dapprich S, Daniels A D, Farkas Ö,
Foresman J B, Ortiz J V, Cioslowski J and Fox D J 2009 Gaussian09, Gaussian, Inc., Wallingford CT

15. Chai J D and Head-Gordon M 2008 Phys. Chem. Chem. Phys. 106615

16. Krishnan R, Binkley J S, Seeger R and Pople J A 1980 J. Chem. Phys. 72650

17. McLean A D and Chandler G S 1980 J. Chem. Phys. 72 5639

18. Boys S F and Bernardi F 1970 Mol. Phys. 19553

19. Biegler-König F and Schönbohm J 2000 AIM 2000. University of Applied Sciences, Bielefeld, Germany

20. Su P F and Li H 2009 J. Chem. Phys. 131014102

21. Schmidt $M$ W, Baldridge $K \mathrm{~K}$, Boatz J A, Elbert S T, Gordon M S, Jensen J H, Koseki S, Matsunaga $\mathrm{N}$, Nguyen K A, Su S, Windus T L, Dupuis M and Montgomery J A 1993 J. Comput. Chem. 141347

22. Sopchak D and Miller B 2000 J. Phys. Chem. A 104 7545

23. Tian S X 2004 J. Phys. Chem. B 10820388

24. Bondi A 1964 J. Phys. Chem. 68441

25. Galvez O, Gomez P C and Pacios L F 2003 J. Chem. Phys. 1184878

26. Miao R, Jin C, Yang G S, Hong J, Zhao C M and Zhu L G 2005 J. Phys. Chem. A 1092340

27. Nozad A G, Meftah S, Ghasemi M H, Kiyani R A and Aghazadeh M 2009 Biophys. Chem. 14149

28. Parreira R L T, Valdes H and Galembeck S E 2006 Chem. Phys. 33196

29. Zhou H W, Lai W P, Zhang Z Q, Li W K and Cheung H Y 2009 J. Comput. Aided Mol. Des. 23153

30. Koch U and Popelier P L A 1995 J. Phys. Chem. 999747

31. Popelier P L A 2000 Atoms in molecules: An introduction, London: Prentice Hall

32. Arnold W D and Oldfield E 2000 J. Am. Chem. Soc. 122 12835

33. Pacios L F 2004 J. Phys. Chem. A 1081177

34. Alkorta I, Rozas I and Elguero J 1998 Chem. Soc. Rev. 27163 